\title{
The $R \& D$ and innovation activity of agribusiness enterprises in Hajdú-Bihar County
}

\author{
Szabolcs Németh \\ University of Debrecen Centre for Agricultural and Applied Economic Sciences, Faculty of Agricultural and Food Sciences and \\ Environmental Management, Kerpley Kálmán Doctoral School of Crop Production, Horticulture and Regional Sciences, Debrecen \\ nemeth@agr.unideb.hu
}

\section{SUMMARY}

Economic changes have significantly accelarated in the $21^{\text {th }}$ century. In this turbulent market environment enterprises are forced to adapt continously as they must be flexible in order to meet changing market needs. To achieve flexibility companies require innovation. The economic relevance of innovations is significant in every market sector and agriculture is no exception. Re-dynamizing agricultural innovations is a possibility for the outburst of the Hungarian agriculture. Agricultural enterprises have to face competitors as well and they should give priority to efficiency, sustainability and competitiveness in order to preserve their position in BOTH global and domestic markets. This study examines the innovation potential of the agricultural enterprises in the North Great Plain region based on own databases and case studies.

Keywords: agribusiness, innovation, enterprise, $R \& D$

\section{ÖSSZEFOGLALÁS}

A 21. századra a gazdasági változások jelentősen felgyorsultak. Ebben a turbulens piaci környezetben a vállalkozások folyamatos alkalmazkodásra vannak kényszeritve, hiszen rugalmasnak kell lenniük a változó piaci igények kielégitése érdekében. A cégeknek, a kereslettel szemben támasztott flexibilitás érdekében innovációra van szükségük. Az innovációk gazdasági relevanciája minden piaci szektorban jelentös, nem kivétel ez alól az agrárgazdaság sem. A magyar agrárium számára a kitörés egyik lehetösége az agrárinnováció ismételt lendületbe hozása. Nekik is szembe kell nézniük a versenytársakkal és elötérbe kell helyezniük a hatékonyság, fenntarthatóság és versenyképesség fogalmát, hogy megörizzék pozíciójukat akár a globális, akár a hazai piacokon. A tanulmány az Észak-alföldi régió agrárjellegü vállalkozásainak innovációs potenciálját vizsgálja publikus adatbázisok és esettenulmányok alapján.

Kulcsszavak: mezögazdasági üzlet, innováció, vállalkozás, $R \& D$

\section{INTRODUCTION}

The matter of innovation progresses is closely related to areas of economic growth, regional competitiveness and knowledge transfer. A significant consequence of the globalization processes is the effacement of the national level. According to the representation of the regional economy, the significance of innovation appears in enterprises and other organizations' regional radiation and in the effect of technological development on the economic growth of regional units (Nolte, 1996; Döry, 2005). Factors closely related to innovations (innovation culture, $\mathrm{K}+\mathrm{F}$ ) are shown in the pyramid model both as basic factor and key success factor, having direct and indirect effects on basic cathegories that determine regional competitiveness (earnings, productivity, employment) (Lengyel, 2003). According to the authors, Asheim and Cooke (1999), for the development of dynamically progressive regions, beside the high autonomy of regional economy and politics, management in connection with innovation progresses, cooperative mentality and the culture as the operator of the main priority (connection between economy-creating jobsand innovation) are also essential. The understanding of the regional operation of innovation progresses is helped by different regional innovation systems (models). This study deals with the conception of regional innovation systems (hereafter RIS). The starting point of the system is the innovation potential, which means that all participants are considered to be the part of the system who indirectly and/or directly or even interfere the innovation to come into existence. According to
Cook (1998), RIS is based on two sub-systems: knowledge creator and user sub-systems. The author draws the attention for the fact that the system works efficiently only if the two sub-systems learns from each other systematically and interactively.

\section{AIMS OF RESEARCH}

This study; based on the conception of regional innovation systems, makes an attempt on examining the $\mathrm{R}+\mathrm{D}$ and innovation activities of enterprises in the North-Plain region and recognising the factors that obstruct innovation processes. Beside revealing a general survey, the study looks for a connection between the size of enterprises (income, number of employees) and the innovation activity, as well as the research and development (hereafter R+D) and innovation activities. Doing all these by setting out from the extended conception of the agrarian sector, which is; beside the scientific curiosity, explained by the past and present of the region's economic, social and natural environment.

\section{MATERIAL AND METHODS}

During composing the investigational sample I took three criteria into consideration: regional level, the size of enterprises and the classification of the sector.

In the course of the sizing standardization of enterprises ususally two view-points are taken into consideration: the number of employees and the yearly net revenue. By the number of employees: In case of less than 10 people it is a small-; less than 250 people it is a middle 
and more than 250 people we can say it is a big enterprise. By their yearly net revenue we can distinguish micro(under 2 million Euros); small- (under 10 million Euros); middle- (under 50 million Euros) and big (50 million Euros or more) enterprises (Net 1). The enterprises that got into the investigational sample were determined by the number of employees. The examination is concentrated on enterprises with 10 or more employees, which is justified for various reasons. On the basis of former researches and observations, in innovation processes and cooperations micro enterprises are less activated than bigger enterprises (Csizmadia and Grosz, 2011). According to Lengyel (2003) small and middle enterprises (hereafter SME) play an important role in the development and competitiveness of regions. On the one hand, SMEs work only in local markets therefore the thing is about nontraded enterprises. On the other hand, the rapidity of restructuring that influences competitiveness mainly depends on SMEs and innovation facilities. Furthermore, the innovation capacity of a particular region means not only an institution that produces knowledge, but mainly corporate capacity, prepared, innovative SMEs in new market sectors and in booming businesses (Camagni, 1995; Lengyel, 2003).

During composing the investigational sample I set out from the idea of agribusiness, which evolved in the 1950 s in the USA. Agribusiness beside food economics involves other economies related to it (e.g. engineering industry, chemical industry), hereby raising the role of agriculture in the national economy (Tracy, 1993). This term can be used exquisitely to map the connections between the participants working in the sector; and in the course of other macroeconomic plannings. The use of agribusiness is also reasonable in case of agrar innovation researches, so we can size up a more accurate idea about $\mathrm{R}+\mathrm{D}$ and innovation processes running in the whole sector. Taking the term of agribusiness as a basis I selected the enterprises by the following TEAOR-08 cathegories: A= agriculture, sylviculture, pisciculture; $\mathrm{CA}=$ (processing industry), food industry, drink and tobacco production; CE_20_202= (processing industry, chemical production), producting agricultural chemicals; CK_28_283= (processing industry, machine and machinery production), agricultural and forestry machinery production.

The examination in the study is connected to my former researches about the university knowledge transfer (in Hajdú-Bihar county) as a sort of environmental diagnostics. From empirical and theoritical studies that occur in specialised literature, it turned out that (economically more relevant) knowledge, which gets out from higher education is able to exert its economy stimulating effects locally (Polányi, 1994; Varga, 2004), therefore I did my research in Hajdú-Bihar county.

In May, 2012219 enterprises fulfilled the requirements above. The query happened in two rounds, in the form of a questionnaire. Altogether 94 enterprises posted back the filled questionnaires, which means a $42.92 \%$ back sending rate.

The questions can be divided into four categories of which one consists of the general (so called introductory questions), for example seat, number of employees, rate of foreign share holdings, sales and procurement.
Questions about research and development activities are in the second category (e.g. R+D input, number of $\mathrm{R}+\mathrm{D}$ eployees). The third category referred to innovation activities (cases of types of innovation). Finally, the fourth category dealed with mapping the factors that influence innovation processes (activity of tendering operation, attitude examination). By the results I got an exact idea about the innovation activity and passivity and the influencing factors of the agribusiness enterprises in the county.

\section{RESULTS}

The average number of emloyees is 63 (median $=$ 27 ) and almost every enterprise (98.9\%) is exclusively Hungarian property. $20.2 \%$ of the enterprises are parts of a group of companies whose seat (except one: in Poland) is in Hungary. Their net average income is 1451705920 HUF (median = 368962000 HUF). Considering sales areas, local markets are the first $(39.9 \%)$, and it is followed by the other parts of Hungary (except the North-Plain region) (26.2\%) and finally EU countries (15.8\%) are the third. Regarding their procurement, the most frequent geographical areas are non-EU countries (35.4\%), local markets are the second and on the third place there are other parts of Hungary (except except the North-Plain region) (17.3\%). The enterprises under discussion do much of their procurements $(59.2 \%)$ and sales $(79.2 \%)$ within our borders, therefore they are non-trade enterprises.

\section{$R+D$ ACTIVITY}

Separate examination of research and development activity is necessary because innovation activity and $\mathrm{R}+\mathrm{D}$ activity are not common by all means while running an enterprise. There are plenty of firms that can work out significant innovations without any $\mathrm{R}+\mathrm{D}$ activities on behalf of its competitiveness in the market. Organizational and marketing innovation do not require such an activity but many cases, mainly the introduction of product and process innovation are preceded by serious $\mathrm{R}+\mathrm{D}$ activity. Enterprises were given two questions regarding their $\mathrm{R}+\mathrm{D}$ activities during the last three years: how many percent of their sales revenue are appropriated for $\mathrm{R}+\mathrm{D}$ activities, and how many percent of the employees work in the area of $\mathrm{R}+\mathrm{D}$ (table 1).

$37 \%$ (35) of the enterprises in the questionnaire appropriated some proportion of their incomes for research and development activity. Among those who do $\mathrm{R}+\mathrm{D}$ activities, the average appropriation by their net incomes is $9.34 \%$ (median $=3.50)$. On the basis of the observations within $\mathrm{R}+\mathrm{D}$ appropriations developments are dominant. 16 of the innovative enterprises indicated that a particular number of their employees work in the area of $\mathrm{R}+\mathrm{D}$, which is $5.56 \%$ on the average (median $=$ $1.00)$.

Investigations demonstrated that there is no significant connection between the yearly net revenue and its appropriation for $\mathrm{R}+\mathrm{D}$ of enterprises, however, there is meanly a negative connection between the size of the company (number of employees) and the sums appropriated for $\mathrm{R}+\mathrm{D}$. 
Indicators of R\&D and Innovation activity between 2009-2011 and 2012-2014

\begin{tabular}{|c|c|c|c|c|c|}
\hline Name of subregion & Total & $\begin{array}{l}\text { Number of } \\
\text { interviewed } \\
\text { enterprises }\end{array}$ & $\begin{array}{c}\text { Number of } \\
\text { R\&D } \\
\text { enterprises } \\
\end{array}$ & $\begin{array}{c}\text { Number of innovative } \\
\text { enterprises } \\
2009-2011 \\
\end{array}$ & $\begin{array}{c}\text { Number of innovative } \\
\text { enterprises } \\
2012-2014 \\
\end{array}$ \\
\hline Balmazújváros & 14 & 8 & 2 & 4 & 4 \\
\hline Berettyóújfalu & 25 & 12 & 2 & 2 & 1 \\
\hline Debrecen & 58 & 18 & 7 & 8 & 13 \\
\hline Derecske-Létavértes & 16 & 8 & 3 & 5 & 5 \\
\hline Hajdúhadház & 17 & 5 & 2 & 0 & 2 \\
\hline Hajdúszoboszló & 26 & 11 & 4 & 8 & 7 \\
\hline Polgár & 3 & 2 & 1 & 0 & 1 \\
\hline Püspökladány & 31 & 17 & 9 & 7 & 6 \\
\hline Total & 219 & 94 & 35 & 39 & 44 \\
\hline
\end{tabular}

Source: own edition

\section{INNOVATION ACTIVITY}

I fulfilled the classification of innovation activities of enterprises by representation of the term, innovation in the OECD Oslovian handbook (OECD, 2005). The document distinguishes four kinds of innovation. First is product innovation, which means the release of a new or significantly improved commodity or service. The second one is process innovation that is a new or significantly improved technology, process, application, production process, distributing method or the introduction of an activity that support goods and services. Third is organizational innovation, which means the accomplishment of a new or significantly improved organizational method in the business practice of the company, organization of work or external relations. Organizational innovation can bring new ways on the following fields: business practice, processes in connection with work organization and management systems, workplace structure, which can result in new organizational structures and new proceedings of decision-making; furthermore in external relations that means the aspect of contact with other companies and national research institutes. The last is marketing innovation, which means the application of new or significantly improved marketing methods on behalf of the aggrandizement of sales; taking aim at consumer's needs, opening of new markets or emplacement of the products to a new target market. Marketing innovation is the application of such new marketing methods that bring significant changes in product planning, packing, product launching, product advertising or pricing (Csizmadia and Grosz, 2011).

The consisted of two parts: one part of the questions oriented on the innovation activity of the last three years and the other referred to the next three years. This way I could distinguish active and passive enterprises in the respect of their innovation activity. Almost $42 \%$ of the enterprises can be regarded as innovative enterprises, since during the examined period (2009-2011) 39 enterprises introduced some kind of innovation (table 1). The distribution of enterprises according to the type of innovation is shown in table 2.

In the period between 2009 and 2011 product (20) and process innovation (22) were the mostly introduced types. In reference to the following three years 44 enterprises plan to introduce new innovations. Examining the question in more details it can be stated that among innovative enterprises (39) 4 do not plan, but among previously non-innovative enterprises (55) 9 plan to introduce new innovations, so passivity about innovations has relatively reduced. Changings do not increase drastically the number of innovation enterprises, since probably, altogether 5 enterprises will become innovative, which is still less (44) than the half of the respondents. In the case of types of innovation it is not likely that strong changings will happen, since according to the forecasts, product and process innovation will be rampant henceforward.

Hypotheses examinations could not find any significant connections between innovation and $\mathrm{R}+\mathrm{D}$ activities, which proves the experience mentioned formerly, that $\mathrm{R}+\mathrm{D}$ activities of enterprises does not necessarily follow that they introduce new innovations, as relevant innovations for enterprises can be bought on markets as well.

Table 2 .

Number of types of innovation between 2009-2011 and 2012-2014

\begin{tabular}{lcc}
\hline \multicolumn{1}{c}{ Types of innovation } & $\begin{array}{c}\text { Number of cases } \\
\text { 2009-2011 }\end{array}$ & $\begin{array}{c}\text { Number of cases } \\
\text { 2012-2014 }\end{array}$ \\
\hline Product innovation & 20 & 23 \\
Process innovation & 22 & 23 \\
Organisational innovation & 6 & 10 \\
Marketing innovation & 9 & 14 \\
Total & 57 & 70 \\
\hline
\end{tabular}

Source: own edition

\section{HINDERING FACTORS OF INNOVATION ACTIVITY}

Factors that influence innovation activity can be divided into two groups according as producing direct or indirect effects. Either group consists of macro factors that influence innovation activities of enterprises mostly indirectly. It includes unpredictably and rapidly changing economic and legal conditions, bureaucracy and unreasonable administration, mistrust beetween business partners and the lack of professional labour force. The other group consists of local/regional factors, 
which have a direct influence on the innovation activity of enterprises. Here we can mention the lack of source of funds within or outside the enterprises, difficulties in gaining information for innovation and the background requirements for successful achievements (Csizmadia and Grosz, 2011). Related to the topics, I examinded the tendering operation activity of enterprises in obtaining innovation resources (EU, state and regional sources). I did an attitude examination for reckoning the strength of hindering factors (with the use of a scale 1-5) (table 3). Examination includesinnovative and non-innovative enterprises as well, because both group's observations mean relevant results. In non-innovative enterprises, obstructing factors rather refer to their successful work and competitiveness, but in many cases there must be particular reasons for not introducing innovation in the examined period.
It has turned out from the results that almost all macro factors have influence on innovation activity of enterprises. The strongest effect is caused by unpredictably changing economic situation, but bureaucracy and rapidly changing legal background do not drop behind much. On the regional level the influencing effect of the lack of internal and external resources and the lack of concurrent partners seem to be dominant. I did the examination in innovative enterprises separately as well and the classification I got is exactly the same as the whole analysis.

Tendering operation activity is extremely low. In the last three years, only 7 enterprises of the 94 took part in a tender for innovation and/or $\mathrm{R}+\mathrm{D}$ activity resources, and its success rate is $72.86 \%$ on the average $($ median $=80.00)$, which can give an explanation on the strong influencing effect of the lack of external resources on innovation (table 3).

Hindering Factors of Innovation Activity in 2012

\begin{tabular}{|c|c|c|c|}
\hline Factors of macro & Mean & Median & Modus \\
\hline Lack of qualified labour & 3.01 & 3 & 3 \\
\hline Mistrust among business actors & 3.42 & 4 & 4 \\
\hline Bureaucracy, excessive administrative & 4.36 & 5 & 5 \\
\hline Unpedictable, uncertain economic environment & 4.43 & 5 & 5 \\
\hline Difficulty of access to local scientific and technological infrastructure and support services & 2.71 & 3 & 3 \\
\hline Difficulty of access to innovation support services & 2.79 & 3 & 3 \\
\hline Difficulty of access to market information & 2.92 & 3 & 3 \\
\hline Difficulty of finding suitable cooperation partners & 3.25 & 3 & 3 \\
\hline Lack of available external financial resources & 3.91 & 4 & 5 \\
\hline Lack of capital within the firm & 3.90 & 4 & 5 \\
\hline
\end{tabular}

Source: own edition

\section{CONCLUSIONS}

Examining Hajdú-Bihar county's enterprises, the results show that one third of the inquired companies did $\mathrm{R}+\mathrm{D}$ activity in the period, in which the rate of developments is bigger. It has turned out that there is no connection between $\mathrm{R}+\mathrm{D}$ and innovation activity, so innovative enterprises do not only make innovation by their own researches, but they can achieve it by other ways (e.g. purchasing). Innovation activity of the agrar sector on the regional level is mostly obstructed by the lack of external and internal resources and it is documented by the weak tendering activity toward resources. On the macro level, bureaucracy and turbulent changes in economic and legal background also have a significant obstructing effect. For raising innovation activity it is necessary to reduce obstructing factors (e.g. preferring cooperations, up-to date information from resources, which can be effective, interactive cooperation between the knowledge producers and users etc.), and higher education can also help with it.

\section{ACKNOWLEDGEMENT}

The publication prepared by TÁMOP-4.2.2/B10/1-2010-0024 project.

The project is supported by European Union, by the European Social co-funding.

\section{REFERENCES}

Asheim, B. T.-Cooke, P. (1999): Local Leraning and Interactive Innovation Networks in a Global Economy. [In: Malecki, E. J.Onias, P. (eds.) Making Connections. Technological Learning and Economic Change.] Ahsgate. Aldershot. 145-178.

Camagni, R. P. (1995): The concept of innovative milieu and its relevance for public policies in european lagging regions. Papers in Regional Science: The Journal of the RSAI. 74. 4: 317-340.
Cooke, P. (1998): Origins of the Concept. [In: Braczky, H. J.-Cooke, P.-Heidenreich, M. (eds.) Regional Innovation Systems.] The Role of Governances in a Globalized World. UCL Press. London. 2-27.

Csizmadia Z.-Grosz A. (2011): Innováció és együttműködés. A kapcsolathálózatok innovációra gyakorolt hatása. MTA RKK. PécsGyőr. 
Dőry T. (2005): Regionális innovációs politika. Kihívások az Európai Unióban és Magyarországon. Dialóg Campus Kiadó. Budapest-Pécs.

Lengyel I. (2003): Verseny és területi fejlődés. Térségek versenyképessége Magyarországon. JATEPress. Szeged.

Net1: http://ec.europa.eu/enterprise/policies/sme/facts-figures-analysis/ sme-definition/index_hu.htm

Nolte, B. (1996): Engpassfaktoren der Innovation und Innovationinfrastruktur. Eine theoretische und empirische Analyse für ländliche Wirtschaftsräume in Baden-Württember. Hohenheimer Volkswirtschaftliche Schriften. Peter Lang Verlag. Frankfurt am Main. Berlin-Bern-New York-Párizs-Wien.
OECD (2005): Oslo Manual. Guidelines for Collecting and Interpreting Innovation Data. Third Edition. OECD. Eurostat. Paris.

Polányi M. (1994): Személyes tudás. Atlantisz Kiadó. Budapest.

Tracy, M. (1993): Food and Agriculture In a Market Economy APS Agricultural Policy Studies. Belgium.

Varga A. (2004): Az egyetemi kutatások regionális gazdasági hatásai a nemzetközi szakirodalom tükrében. Közgazdasági Szemle. 51. 3: 259-275. 
